\title{
Compensation for Land Procurement for the Construction of the Northern Ring Road of Solok City by the Regional Government of Solok
}

\author{
Weri Zakia; Kurnia Warman; Frenadin Adegustara \\ Faculty of Law, Andalas University, Padang, Indonesia
}

http://dx.doi.org/10.18415/ijmmu.v6i3.874

\begin{abstract}
This study aims to analyze compensation for land procurement for the construction of the northern ring road of Solok City by the Regional Government of Solok. The main approach method used is a research that emphasizes legal aspects by studying primary and secondary legal materials. It will later become a guideline for understanding and analyzing research problems. In addition, an empirical juridical approach is used as a support for the main approach. The results showed that the implementation of land procurement for the northern ring road of Solok City directly between Regional Government Agencies of Solok and landowners or their attorneys was carried out with the release of rights to land, buildings and objects associated with it under the principle of deliberation. It is in accordance with Article 10 of the Law of the Republic of Indonesia No. 2 of 2012 jo. Presidential Regulation of the Republic of Indonesia No. 71 of 2012. Regarding the determination of compensation carried out by means of deliberations between Government Agencies through the Land Procurement Team and landowners and their attorneys, based on the appraisal team's assessment results, the basis for the assessment is fair replacement value and/or proper and fair replacement. It is in accordance with Article 10 of the Law of the Republic of Indonesia No. 2 of 2012 concerning Land Procurement for Development in the Public Interest and Presidential Regulation of the Republic of Indonesia No. 71 of 2012 concerning the Implementation of Land Procurement for Development in the Public Interest.
\end{abstract}

Keywords: Compensation; Land Procurement; Road Construction

\section{Introduction}

The construction of the northern ring road is an activity listed in one of the visions and missions of Solok Mayor, Syamsu Rahim, also included in the Regional Regulation of Solok City No. 1 of 2007 concerning the Solok City Spatial Planning which was later amended by Regional Regulation of Solok City No. 13 of 2012 concerning Solok City Spatial Planning for 2012-2031.

The northern ring road is included in the category of arterial roads that connect Solok City with Solok Regency which includes Padang City, Padang Panjang City, Tanah Datar Regency and Sawah 
Lunto/ Sijunjung Regency. ${ }^{1}$ Then, it was changed to Regional Regulation of Solok City No. 13 of 2012 that the northern ring road is included in the development planning of the ring road. ${ }^{2}$

In Article 9 paragraph (2) of the Law of the Republic of Indonesia No. 2 of 2012 concerning Land Procurement for Development in the Public Interest, it is stated that land procurement for public interest is carried out by providing compensation in a proper and fair manner. The northern ring road built by the Regional Government of Solok will later be used as a public road as in accordance with Article 10 letter (b) of the Law of the Republic of Indonesia No. 2 of 2012 concerning Land Procurement for Development in the Public Interest.

The practice of land procurement for development so far has been carried out by the government through a long tiring process. It also takes a long time and does cost a lot of money. Infrastructure development is the development sector most affected by the difficulty of land procurement. Facts on the field show that problems and obstacles never seem to recede. It is what the Regional Government of Solok has done in the construction of the Northern Ring Road which has been designed since $2007 .{ }^{3}$ Until now, the northern ring road which is a transportation infrastructure is still not effective. There are still people around the construction of the road who are facing obstacles to relinquish their land rights because the compensation that the government provides is not in accordance with the selling price of the land. In addition, some land experienced obstacles in the administrative process (completeness of evidence/ rights).

On the other hand, there were people who blocked the construction of the road because the land was owned by their people who had not yet agreed to relinquish the land.

The construction of the northern ring road has been planned since 2007 and is included in the 2014 Mayor's Decree on the Determination of Locations for the Procurement of Land for the Construction of the Northern Ring Road of Solok City held in accordance with the Law of the Republic of Indonesia No. 02 of 2012 concerning Land Procurement for Development in the Public Interest.

Regarding the basis and method of calculating compensation, based on Law No. 2 of 2012 concerning Land Procurement for Development in the Public Interest, compensation is a proper and fair replacement to the entitled parties in the land procurement process. Presidential Regulation of the Republic of Indonesia No. 71 of 2012 concerning the Implementation of the procurement of Land for Development in the Public Interest also states that compensation is a proper and fair replacement to the entitled parties in the land procurement process.

According to Article 31 of the Law of the Republic of Indonesia No. 02 of 2012 concerning Land Procurement for Development in the Public Interest related to the assessment of compensation assessed by the appraiser, the appraisal team is determined by the Land Agency. In this case, the Regional Government of Solok has appointed Public Appraisal Services, Muttaqin Bambang Purwanto Rozak Uswatun and friends.

Under Article 33 of the Law of the Republic of Indonesia No. 2 of 2012 concerning Land Procurement for Development in the Public Interest, an assessment of the amount of compensation value by the appraiser is carried out in the field per land plots which includes:

1. Soil;

2. Land and basement space;

3. Building;

\footnotetext{
${ }^{1}$ Regional Regulation of Solok City No. 1 of 2007 concerning Solok City Spatial Planning, Regional Gazette of Solok City in 2007, Article 16

2 Regional Regulation of Solok City No. 13 of 2012 concerning Solok City Spatial Planning for 2012-2031, Regional Gazette of Solok City in 2012, Article 16, Article 11

${ }^{3}$ Interview with Alfi Adli, Village Head of Tanah Garam Village on November 10, 2016
} 
4. Plant;

5. Objects related to land;

6. Other losses that can be assessed.

Similar matter is also mentioned in Article 65 of the Presidential Regulation of the Republic of Indonesia No. 71 of 2012 concerning the Implementation of Land Procurement for Development in the Public Interest and Article 23 of the Regulation of the Head of the National Land Agency of the Republic of Indonesia No. 5 of 2012 concerning Implementation Guidelines for Land Procurement. In the implementation of the construction of the northern ring road, the Regional Government of Solok has taken efforts based on the regulations mentioned above.

\section{Research Method}

The approach and characteristic of the research on the legal problem in the construction of the Northern Ring Road of Solok City is a sociological or empirical legal research, which aims to see the application of legal aspects in the community concerning the implementation of land procurement carried out by the Solok Regional Government. ${ }^{4}$ In addition, this study was conducted using a normative juridical approach in order to analyze the laws and regulations in the field of land procurement implementation in accordance with the research problems. ${ }^{5}$

This research is also descriptive analytical; ${ }^{6}$ i.e. a study aimed at explaining, describing and analyzing data obtained systematically and accurately about the implementation of land procurement for the construction of the northern ring road of Solok City by the Regional Government. In data processing, all data that the authors obtained is grouped for later edited (compiled). After the data is grouped, the data is processed so that it is systematically structured to facilitate the conclusion drawing. In this paper, the authors conducted qualitative data analysis. Qualitative data analysis is a method of data analysis to group and select data obtained from field research according to the quality and truth. Then, it is connected with theories, principles, and legal rules obtained from library studies so that answers to problems - that have been formulated - can be obtained.

\section{Research Results and Discussion}

1. Determining the Form and Amount of Compensation for Land Procurement in the Construction of the Northern Ring Road of Solok City by the Regional Government of Solok

The northern ring road is included in the category of arterial roads that connect Solok City with Solok Regency which includes Padang City, Padang Panjang City, Tanah Datar Regency and Sawah Lunto/ Sijunjung Regency. The construction of northern ring road of Solok City is begun from traffic congestion in the city due to a mixture of local and regional traffic in using the city's main road which is an arterial road. The construction of the northern ring road aims to stimulate growth in development in the northern region of Solok City. Thus, growth does not only occur in the city center in the southern region of Solok City. Therefore, the Solok Regional Government took the initiative to carry out road construction in the northern area of Solok City where the utilization is used for the public interest.

The authority of the Government in procuring land for the implementation of development in the public interest is a priority of the government in providing land for the development of public interests. Constitutionally, the state's right to control is stated in Article 33 paragraph (3) of the 1945 Constitution

\footnotetext{
${ }^{4}$ Coglianese, Cary. "Empirical analysis and administrative law." U. Ill. L. Rev. (2002): 1111.

${ }^{5}$ Wróblewski, Jerzy. The judicial application of law. Vol. 15. Springer Science \& Business Media, 1992.

${ }^{6}$ Calleros, Charles. Legal method and writing. Wolters Kluwer Law \& Business, 2014.
} 
which states: "The earth, water, and natural resources contained therein are controlled by the state and utilized as much as possible for the people's prosperity". Based on this provision, the use of the earth (land), water, and natural resources contained therein is used by the state for the prosperity of the people.

According to the Law of the Republic of Indonesia No. 32 of 2004 concerning Regional Government, Regional Governments are Governor, Regent or Mayor and Regional Staff as elements of regional government administrators. Regional governments, with decentralized system and based on autonomy, must be followed up by the Regional Government to manage their own households based on good governance principles. The government and regional government have different authorities but remain in one unit and in the framework of the prosperity of the people. The land procurement for the implementation of development for the public interest must also prioritize the welfare of the people. In terms of land procurement, there are also rights to land ownership.

In this case, the construction of the northern ring road of Solok City was carried out during the transitional period of legislation so that the determination of the compensation amount at that time used 2 rules. There is a procedure for paying compensation in 2010 so that it applies the Presidential Regulation of the Republic of Indonesia No. 65 of 2006 concerning Amendment to Presidential Regulation No. 36 of 2005 concerning Land Procurement for Implementation of Development for Public Interest. In addition, compensation implemented after 2012 applies the provisions of the Law of the Republic of Indonesia No. 2 of 2012 concerning Land Procurement for Development in the Public Interest.

Determination of the amount of compensation value is carried out by the Chairperson of Land Procurement Managers based on the results of the assessment of public appraisal or appraisal service. Public appraisal or appraisal service are determined by the Chairperson of Land Procurement. ${ }^{7}$

In this case, the Land Office of Solok City, as Chairperson of the Land Procurement Agency for the Construction of Northern Ring Road, determines appraisal services by implementing a work contract between the Regional Government of Solok and appraisal services. It appointed public appraisal services, Muttaqin Bambang Purwanto Rozak Uswatun and friends.

Considering that normative data from valuation objects are in the form of vacant land, land and buildings, and other complementary plants and facilities which do not have some market data that can be used as comparative data, the appraisal team selects an assessment method using a cost approach.

Cost approach is an approach that produces an indication of value by using economic principles in which the buyer will not pay an asset more than the cost of acquiring assets with the same or equivalent use at the time of purchase or construction (2013 Indonesian Assessment Standards, Concepts and General Principles of Assessment -19.1).

The amount of compensation based on the results of the assessment by the appraisal team is conveyed to the chief executive of land procurement through the report on the results of the assessment. The results of the assessment are used as the basis for deliberation to determine the form of losses as contained in Article 34 of the Republic of Indonesia Law No. 2 of 2012 concerning Land Procurement for Development in the Public Interest.

The validation results of the compensation in the land procurement for northern ring road development of Solok City from the beginning of 2014-2018 can be seen in Table 1 .

${ }^{7}$ Ibid. Article 6 
Table 1. The validation results of the compensation in the land procurement for northern ring road development of Solok City

\begin{tabular}{|c|c|c|c|c|c|}
\hline No & Names of Landowner & Location & $\begin{array}{l}\text { Number of Lan } \\
\text { according to Map }\end{array}$ & $\begin{array}{l}\text { Area of Meas } \\
\text { Results }\end{array}$ & $\begin{array}{l}\text { Form } \\
\text { Compensati }\end{array}$ \\
\hline 1 & Syamsuil/ Sutan Mudo & K. Jawa & 1 plot & 2.023 & money \\
\hline 2 & M. Dazar Yatim & Laing & 1 plot & 1.228 & money \\
\hline 3 & Hj. Nursian-Sjamsuil & Laing & 1 plot +tanaman & 577 & money \\
\hline 4 & Jafar/ Chairiza Gafar & Laing & 1 plot & 3.600 & money \\
\hline 5 & Junaidi & Laing & 1 plot + plants & 1.892 & money \\
\hline 6 & Bukik Dt Rj Bujang & Laing & 1 plot + plants & 343 & money \\
\hline 7 & Bukik Dt Rj Bujang & Laing & 1 plot + plants & 613 & money \\
\hline 8 & Bukik Dt Rj Bujang & Laing & 1 plot + plants & 2.648 & money \\
\hline 9 & Nurbaini & Laing & 1 plot + plants & 1.261 & money \\
\hline 10 & Basirin Dt. Rj Bungsu & Laing & 1 plot + plants & 1.755 & money \\
\hline 11 & Yusmanidar & Laing & 1 plot + plants & 1.754 & money \\
\hline 12 & Suwarni/ Upik & Laing & 1 plot & 3.166 & money \\
\hline 13 & Suwarni/ Upik & Laing & 1 plot & 213 & money \\
\hline 14 & Suwarni/ Upik & Laing & 1 plot & 3.166 & money \\
\hline 15 & Suwarni/ Upik & Laing & 1 plot + plants & 3.747 & money \\
\hline 16 & Bukik Dt Rj Bujang & Laing & 1 plot & 769 & money \\
\hline 17 & Yusni & Laing & 1 plot & 894 & money \\
\hline 18 & Yusni & Laing & 1 plot + shop & 1.049 & money \\
\hline 19 & Bukik Dt Rj Bujang & Laing & 1 plot & 1.059 & money \\
\hline 20 & Suin Dt. Bungsu & Laing & 1 plot & 635 & money \\
\hline 21 & Zaibir Dt. Panduko Basa & Laing & 1 plot & 1.375 & money \\
\hline 22 & Syafrida Dt. Rj Langik & Laing & 1 plot & 559 & money \\
\hline 23 & Samauyah-Yurnalis & Laing & 1 plot + plants & 1.241 & money \\
\hline 25 & Zulkariadi & Laing & 1 plot & 205 & money \\
\hline 26 & Darmiati & Laing & 1 plot + plants & 391 & money \\
\hline 27 & Lusi Marliastuti & Laing & 1 plot & 91 & money \\
\hline 28 & Masdayanti & Laing & 1 plot & 705 & money \\
\hline 29 & Dt. Sari Marajo & Tanah Garam & 1 plot & 565 & money \\
\hline 30 & Nawas & Nan Balimo & 1 plot & 565 & money \\
\hline 31 & Nurma & Laing & 1 plot + house bui & 878 & money \\
\hline 32 & Yenita & Laing & 1 plot & 511 & land \\
\hline 33 & Sahrul & Laing & 1 plot + fence & 18 & $\begin{array}{l}\text { replacement } \\
\text { fence }\end{array}$ \\
\hline
\end{tabular}




\begin{tabular}{|c|c|c|c|c|c|}
\hline 34 & Hj. Rabiah & Nan Balimo & 1 plot & 800 & money \\
\hline 35 & Fasum & & 1 plot & 410 & no compens \\
\hline 36 & Harmaini/ Evarina & Laing & 1 plot & 410 & land \\
\hline 37 & Zaibir & Laing & 1 plot & 1.208 & money \\
\hline 38 & Zaibir & Laing & 1 plot + plants & 1.980 & money \\
\hline 39 & Kaciak basa & Laing & 1 plot & 1.741 & money \\
\hline 40 & Samawir Dt. Rj Kumbang & Laing & 1 plot & 646 & money \\
\hline 41 & Nursian, Cs & Laing & 1 plot & 968 & money \\
\hline 42 & Asnimar & Laing & 1 plot & 134 & money \\
\hline 43 & Mutahar Us Basyarudin & Laing & 1 plot & 3.573 & money \\
\hline 44 & Asnidar/ Dt. Rj Langik & Laing & 1 plot + plants & 1.980 & money \\
\hline 45 & Masrial & Laing & 1 plot + plants & 1.048 & money \\
\hline 46 & Masrial & Laing & 1 plot + plants & 21 & money \\
\hline 47 & Hj. Nursani & Laing & 1 plot + plants & 2.351 & money \\
\hline 48 & Nurlena & Laing & 1 plot & 410 & money \\
\hline 49 & Hj. Nursani & Laing & 1 plot & 406 & money \\
\hline 50 & Nursili, Arbaini, Ratnawili & Laing & 1 plot & 2.219 & money \\
\hline 51 & Rosmanidar & Laing & 1 plot & 795 & not yet \\
\hline 52 & Arbiyani & Laing & 1 plot + building & 669 & money \\
\hline 53 & Bukri Dt. Juaro Kuniang & Laing & $\begin{array}{l}1 \text { plot }+ \text { house bu } \\
\text { plants }\end{array}$ & 2.341 & money \\
\hline 54 & Yasir Dt. Putih & Laing & $\begin{array}{l}1 \text { plot }+ \text { house bu } \\
\text { plants }\end{array}$ & 265 & money \\
\hline 55 & Former Head of the Village & Laing & 1 plot + plants & 274 & no compens \\
\hline 56 & Nurbaya (railroad track) & Laing & 1 plot & 274 & no compens \\
\hline
\end{tabular}

\section{Submission of the Results}

The chairman of land procurement for the construction of the northern ring road of Solok City submitted the results of land procurement to the relevant agencies. In this case, it was submitted to the Public Works Agency of Solok in conjunction with the data and parties who had relinquished their land for the construction of the northern ring road of Solok City, no later than 7 (seven) working days from the release of the land procurement object rights. Submission of the results was supplemented by an official report which was subsequently used by the Public Works Agency of Solok to register the land certificate into the land belonging to the Regional Government of Solok.

As contained in Article 112 of the Presidential Regulation of the Republic of Indonesia No. 71 of 2012 concerning the Implementation of Land Procurement for Development in the Public Interest, it was stated that:

a. The chairman of land procurement hands over the results of land procurement to agencies that require the land and is accompanied by land procurement data, no later than 7 (seven) days after the release of the object of land procurement rights; 
b. Submission of results of land procurement is in the form of land plots and land procurement documents;

c. Submission of the results of land procurement is carried out with reports to be subsequently used by agencies requiring land for registration/ certification;

d. Registration/ certification must be carried out by agencies that require land within 30 (thirty) days from the submission of the results of land procurement.

After that the Public Works Agency of Solok can begin the construction of the northern ring road of Solok City.

\section{Provision of Compensation for Land Procurement for the Construction of the Northern Ring Road of Solok City by the Regional Government of Solok}

In the construction of the northern ring road, there are 2 (two) differences in regulations so that the submission of compensation for land procurement for the northern ring road of Solok City also has 2 (two) differences.

Submission of compensation for land procurement for the construction of the northern ring road of Solok City which was implemented in 2010, applied Presidential Regulation No. 65 of 2006 concerning Amendment to Presidential Regulation No. 36 of 2005 concerning Land Procurement for the Implementation of Development in the Public Interest which also refers to the Regulation of the Head of the National Land Agency of the Republic of Indonesia No. 3 of 2007 concerning Presidential Regulation No. 36 of 2005 concerning Land Procurement for Implementation of Development in the Public Interest as amended by Presidential Regulation No. 65 of 2006 Land Procurement for the Implementation of Development in the Public Interest.

Submission of compensation for land procurement for the construction of the northern ring road of Solok City only exists in 2 (two) forms as follows:

a. Money

b. Replacement for the land

The basis for granting compensation is the result of a consensus agreement between the parties entitled to the implementation of the construction of the northern ring road of Solok City as outlined in the agreement report. The chief executive of the land procurement for the construction of the Solok City northern ring road submitted an agreement report to the Public Works Agency of Solok.

The form of compensation is given in accordance with the compensation value which nominal is equal to the value set by the Appraisal Team. The land procurement provider determines the form of compensation based on the agreement report. Compensation in the form of money is given in the form of rupiah. Provision of compensation in the form of money is carried out by the Public Works Agency of Solok based on validation from the Chairperson of Land Procurement.

As stated in Article 75 of the Republic of Indonesia Regulation concerning the Implementation of Land for Development in the Public Interest, it is stated that:

a. In a deliberation, the land procurement executor prioritizes compensation in the form of money;

b. The land procurement executor makes a determination regarding the form of loss based on the agreement report.

The processes of submitting compensation, in the form of money on the land procurement for the construction of the northern ring road of Solok City, are as follows: 
a. The concerned parties are summoned or invited by the Solok City government section by carrying out the requirements discussed earlier in the agreement meeting which include:

1) Copy of the ID Card of the concerned party. If it is authorized, it must have a power of attorney issued by the local Notary Office;

2) If the object has been certified, the concerned party must carry the original certificate;

3) If the land has not been certified, it must be completed with the basis of rights, commensurate limits, family lineage, and recommendations from the Village Office;

4) Bank account book.

b. The concerned parties sign a stamped statement regarding the release of rights and agreement report for the determination of compensation in the form of money;

c. After all material requirements are complete, it is the government's turn to send the material to the Land Office of Solok City;

d. Solok City Land Office checks the materials and records them in the registration number. If the materials are complete, they will be sent to the Public Works and Spatial Planning Agency of Solok. However, if the materials are still incomplete, the Land Office of Solok City returns the materials to the Solok City Government to contact the again the concerned party;

e. If the material has been received by the Public Works and Spatial Planning Agency of Solok, the treasurer or the official finance department will make a request for funds to the Regional Finance Agency of Solok City;

f. Within 1 (one) week of work day since the application is received by the Public Works and Spatial Planning Agency, the Financial Agency makes a Fund Disbursement Order directly sent to the account number of the concerned party

g. If all parties concerned have received compensation, the materials are sent back to Land Office of Solok City to be archived.

h. The Land Office of Solok City will issue certificates of land objects that have been released into certificates on behalf of the Regional Government of Solok.

As contained in Article 27 of the Regulation of the Head of the National Land Agency of the Republic of Indonesia No. 5 of 2012 concerning Land Procurement Implementation Guidelines, it is stated that:

a. Provision of compensation is carried out along with the release of rights by the concerned party;

b. The release by the concerned party is accompanied by the submission of proof of ownership of land rights to the executor of land procurement;

c. Provision of compensation is evidenced by a receipt for compensation made in 3 (three) copies;

d. Provision of compensation and release of rights is made in the report of compensation and release of rights;

e. The signing of the compensation report and the release of rights is carried out simultaneously;

f. Reports of compensation in the form of money and reports on the release of rights in accordance with the stipulated attachments;

g. The implementation of compensation is documented with photos/ videos.

The process of submitting compensation in the form of replacement for land in the land procurement in the northern ring road of Solok City is as follows: 
a. The concerned parties are summoned or invited by the Solok City government section by carrying out the requirements discussed earlier in the agreement meeting which include:

1) Copy of the ID Card of the concerned party. If it is authorized, it must have a power of attorney issued by the local Notary Office;

2) If the object has been certified, the concerned party must carry the original certificate;

3) If the land has not been certified, it must be completed with the basis of rights, commensurate limits, family lineage, and recommendations from the Village Office;

b. The concerned parties sign a statement stating the release of rights and the agreement report for the determination of compensation in the form of land. Provision of compensation in the form of land is carried out along with the release of rights by the concerned party without waiting for the availability of replacement land;

c. After all material requirements are complete, it is the government's turn to send the material to the Land Office of Solok City;

d. Solok City Land Office checks the materials and records them in the registration number. If the materials are complete, they will be sent to the Public Works and Spatial Planning Agency of Solok. However, if the materials are still incomplete, the Land Office of Solok City returns the materials to the Solok City Government to contact the again the concerned party;

e. In the event that materials have been received by the Public Works and the Spatial Planning Agency of Solok City, the treasurer or department of finance will make a request for funds for the provision of replacement land to the Regional Finance Agency of Solok City;

f. During the process of providing the replacement land, the funds for providing replacement land are deposited with the bank by and on behalf of the Public Works and Spatial Planning Agency of Solok City;

g. The implementation of the provision of replacement land is carried out no later than 6 (six) months after the determination of compensation by the implementer of land procurement.

h. If all concerned parties have received compensation, the material is sent back to the Land Office of Solok City to be archived.

i. Land Office of Solok City will issue a certificate of land object that has been released into a certificate on behalf of the Regional Government of Solok and issue a replacement certificate on behalf of the concerned parties.

It is stated in Article 29 of the Regulation of the Head of the National Land Agency of the Republic of Indonesia No. 5 of 2012 concerning Land Acquisition Implementation Guidelines stating that:

a. Regarding compensation agreements in the form of replacement land, agencies that require land to provide replacement land no later than 6 (six) months from the determination of compensation by the executor of land procurement;

b. Release of rights by the concerned parties is carried out when the location of the land has been agreed;

c. Release of rights by the concerned parties is carried out without waiting for replacement land;

d. Regarding agencies requiring land to have acquired replacement land and agreed to by the concerned party, the agency that needs land hands over the land to the concerned party after obtaining validation from the chief executive of land procurement; 
e. Submission of replacement land is made in the compensation submission report in the form of replacement land;

f. The delivery of compensation in the form of replacement land is documented with photos/ videos.

\section{Conclusion}

1. Determination of compensation for the northern ring road of Solok City in 2010 was guided by Presidential Regulation No. 65 of 2006 concerning Amendment to Presidential Regulation No. 36 of 2005 concerning Land Procurement for the Implementation of Development for the Public Interest. The basis for calculating the amount of compensation is based on the selling value of the tax object. Meanwhile, the process of determining the form and amount of compensation in the land procurement for the construction of the northern ring road of Solok City by the Regional Government of Solok in 2012 is in accordance with Law No. 2 of 2012 concerning the land procurement for development in the public interest is to provide proper and fair compensation.

2. Submission of compensation in the land procurement for the construction of the northern ring road of Solok City by the Regional Government in 2010 is given directly to the concerned parties. Meanwhile, the submission of compensation in the land procurement for the construction of the northern ring road of Solok City by the Regional Government of Solok in 2012 was carried out by transfer to the accounts of each concerned party in accordance with the agreement report.

Regarding land procurement for the northern ring road of Solok City, until now it has not been completed because there are still several plots of land that cannot be compensated due to internal problems with the landowners concerned. However, the Solok City Government still wants to approach them by conducting some deliberation efforts with the landowners who are living in Laing Village.

\section{References}

Calleros, Charles. Legal method and writing. Wolters Kluwer Law \& Business, 2014.

Coglianese, Cary. "Empirical analysis and administrative law." U. Ill. L. Rev. (2002): 1111.

Law No. 2 of 2012 concerning Land Procurement for Public Interest.

Presidential Regulation No. 36 of 2005 concerning Land Procurement for Development in the Public Interest.

Regional Regulation of Solok City No. 1 of 2007 concerning Solok City Spatial Planning.

Regional Regulation of Solok City No. 13 of 2012 concerning Solok City Spatial Planning for 2012-2031. Wróblewski, Jerzy. The judicial application of law. Vol. 15. Springer Science \& Business Media, 1992.

\section{Copyrights}

Copyright for this article is retained by the author(s), with first publication rights granted to the journal. This is an open-access article distributed under the terms and conditions of the Creative Commons Attribution license (http://creativecommons.org/licenses/by/4.0/). 